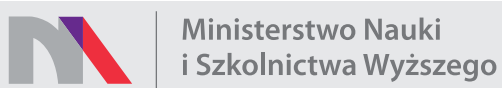

Digitalizacja archiwalnych numerów czasopisma naukowego Analecta Cracoviensia 1-24 (1969-1992) i ich publikacja w otwartym dostępie - zadanie finansowane w ramach umowy 672/P-DUN/2017 ze środków Ministra Nauki i Szkolnictwa Wyższego przeznaczonych na działalność upowszechniającą naukę

\title{
NAD NIEOMYLNOŚCIĄ KOŚCIOŁA
}

Już od 1967 r. toczy się w Kościele katolickim dyskusja nad zagadnieniem nieomylności Kościoła, rozpoczęta przez H. Künga, profesora teologii dogmatycznej i ekumenicznej na uniwersytecie w Tübingen, publikacją dwóch książek: Die Kirche ${ }^{1}$, a zwłaszcza Unfehlbar? Eine Anfra$g e^{2}$. Ta największa kontrowersja teologiczna po II Soborze Watykańskim zainteresowała nie tylko szerokie grono specjalistów na całym świecie, lecz przeniknęła także do szerokiej opinii publicznej chrześcijan dzięki środkom masowego przekazu.

W tej sytuacji również rzymska Kongregacja Nauki Wiary nie mogła pozostać na uboczu i w 1971 r. wszczęła oficjalne postępowanie w sprawie Künga przekazując mu do ustosunkowania się listę twierdzeń nastręczających trudności katolickiej interpretacji. Odpowiedź otrzymana od Adresata była wymijająca. Küng broniąc swych poglądów postulował, że należy wpierw rozpatrzyć sam status prawny Kogregacji, by zapewnić interpelowanym nie fikcyjną, lecz rzeczywistą obronę ${ }^{3}$. Nadto Küng opublikował wczesną wiosną 1973 r. w zbiorowej pracy Fehlbar? Eine Bilanz opinie niektórych teologów raczej mu przychylnych, zauważając przy tej okazji, że oponenci nie byli w stanie przytoczyć na poparcie swoich tez przekonywujących argumentów. W szczególności nikt nie zdołał przeprowadzić dowodu na możliwość istnienia w teologii i życiu Koś-

1 H. Küng, Die Kirche, Freiburg-Basel-Wien 1967. Por. na ten temat Diskussion um Hans Küng 'Die Kirche', herausgegeben und eingeleitet von $\mathrm{H}$. Häring und I. Nolte, Freiburg-Basel-Wien 1971, zawierającą dokumentację dyskusji, jaką wywołała książka Künga oraz pogłębioną analizę współczesnej problematyki eklezjologicznej.

2 H. Küng, Unfehlbar? Eine Anfrage, Zürich-Einsiedeln-Köln 1970. W 54 t. Quaestiones disputatae K. Rahner zebrał i wydal wypowiedzi 15 teologów pod adresem tej książki: Zum Problem Unfehlbarkeit. Antworten auf die Anfrage von Hans Küng, herausgegeben von K. Rahner, Freiburg-Basel-Wien ${ }^{2} 1972$.

${ }_{3}$ Stanowisko Kongregacji Nauki Wiary i reakcję $H$. Künga $w$ dosłownym brzmieniu zob. w: Fehlbar? Eine Bilanz, herausgegeben von H. Küng, Zürich-Einsiedeln-Köln 1973, 497-509. 
cioła nieomylnych zdań ${ }^{4}$. Publikacja ta niedwuznacznie pokazała, że opisany spór znalazł się $\mathrm{w}$ impasie.

Tak więc doszło do ogłoszenia 5.7.1973 r. przez Rzymską Kongregację Nauki Wiary dokumentu eklezjologicznego pod znamiennym tytułem: „Deklaracja dotyczaca katolickiej nauki o Kościele celem jej obrony przed niektórymi dzisiejszymi błędami” - opatrzonej datą 24.6.1973, a zaaprobowanej przez papieża Pawła VI 11.5.1973 r. Tekst Deklaracji nie wymienia nazwiska Künga. Znalazło się ono tylko w „Uwagach”, jakie abp J. Schröffer poczynił w Watykanie podając ją do publicznej wiadomości na konferencji prasowej ${ }^{5}$. Jednakże wobec dalszego obstawania Künga przy „napiętnowanych” opiniach teologicznych, czego szczególnie dowiodły książki Wozu Priester i Christ sein ${ }^{6}$, Kongregacja Nauki Wiary, tym razem już wymieniając jego nazwisko, wydała nową Deklarację. Deklaracja ta wzmiankuje prace Die Kirche i Unfehlbar? stwierdzając zarazem, że zawierają ,,pewne poglądy, które w różnym stopniu sprzeczne są $\mathrm{z}$ nauką Kościoła katolickiego wyznawaną przez wszystkich wiernych" 7. Prawie równocześnie z tym dokumentem także Konferencje Episkopatu zachodnioniemieckiego i Szwajcarii, a więc władze kościelne, którym Küng bezpośrednio podlega, opublikowały $w$ tej samej sprawie własne oświadczenia ${ }^{8}$. W końcowym słowie swego oświadczenia biskupi zachodnioniemieccy solidaryzując się ze stanowiskiem Kongregacji Nauki Wiary sformułowali pod adresem Künga poważne ostrzeżenie, wyraźnie odbiegające od teologicznego charakteru pozostałych wywodów: „Jeżeli Profesor Küng nie weźmie za podstawę swojej pracy teologicznej w tych zasadach wypowiedzianych norm kościelnej wiary, konflikty z Urzędem Nauczycielskim Kościoła mogą nie ustać" 9.

4 Tamże, 305-493. Wartością teologiczną tej pozycji zajmują się między innymi: S. Horn, Fehlbar oder unfehlbar? Zu Küngs Bilanz der Debatte, "Internazionale katholische Zeitschrift", 1 (1974) 87-91; L. Scheffczyk, Ist das Unfehlbarkeitsdogma widerlegt, Erwägungen zu H. Küng, Fehlbar? Eine Bilanz, „Münchener theologische Zeitschrift", 25 (1974) 51-63.

5 Declaratio circa catholicam doctrinam de Ecclesia contra nonnullos errores hodiernos tuendam, AAS, 65 (1973) 396-408. Tekst polski zarówno Deklaracji jak i Uwag abpa J. Schröffera zob. w: „Życie i Myśl”, 11 (1973) 126—138.

6 H. Küng, Wozu Priester, München - Zürich, 1971; Christ sein, München Zürich 1974.

7 Declaratio de duobus operibus Professoris Joannis Küng, AAS, 67 (1975) 203-204. Tłumaczenie polskie w: „Życie i Myśl”, 6 (1975) 118.

8 Zob. w polskim tłumaczeniu: Oświadczenie Konferencji Episkopatu RFN i Oświadczenie Konferencji Szwajcarii, w: „Życie i Myśl”, 6 (1975) 120-124.

9 ,Wenn Professor Küng die in diesen Prinzipien ausgesprochenen Normen des kirchlichen Glaubens nicht als Grundlage seiner theologischen Arbeit beachtet, können Konflikte mit dem kirchlichen Lehramt nicht ausbleiben", Erklärung der Deutschen Bischofskonferenz zum Abschluss des Lehrverfahrens der Kongregation für die Glaubenslehre zu 'Die Kirche' und 'Unfehlbar? Eine Anfrage' von Prof. Dr. Hans Küng, w: „L'Osservatore Romano. Wochenausgabe in Deutscher Sprache", Nr. 10, 7. März 1975. Należy zwrócić przy tym uwagę, że polskie tłumaczenie Oświadczenia Konferencji Episkopatu RFN, w: „Życie i Myśl”, zniekształca treść przytoczonego tekstu. Tamże, 123. 
Tak więc odrzuciwszy zdecydowanie błędy doktrynalne popełnione przez Künga, zarówno Kongregacja Nauki Wiary jak i Konferencje Episkopatu RFN i Szwajcarii powstrzymały się od wyciągnięcia w stosunku do niego konsekwencji dyscyplinarnych. Nie oznacza to jednak - jak widać - że w ogóle $z$ nich zrezygnowano. Niemniej zastosowana procedura postępowania dała asumpt do mówienia o nowym „modelu”, czy nowym „stylu” traktowania spornych kwestii doktrynalnych w Kościele katolickim ${ }^{10}$.

W przedstawionej kontrowersji chodzi przede wszystkim o katolicki dogmat nieomylności Kościoła Chrystusowego. Rozmiary konfliktu są tak poważne, że dogmat ten i powstała wokół niego dyskusja domagają się rozpatrzenia i pogłębionej analizy zarówno w świetle wiary katolickiej jak i z punktu widzenia aktualnej rozbieżności sądów.

\section{KATOLICKA NAUKA O NIEOMYLNOŚI KOSCIOEA JEZUSA CHRYSTUSA}

Nieomylność Kościoła oznacza, że dane przez Boga ludziom Objawienie, dzięki specjalnej opiece Ducha Świętego, pozostanie zawsze w wierze i przepowiadaniu Kościoła niesfałszowane, tzn. ustrzeżone od błędu w swej istotnej treści ${ }^{11}$.

a) Rozwój doktryny

Tak pojętą nieomylność Chrystus Pan wyraźnie przyrzekł Kościołowi. Przede wszystkim przekazał apostołom swoje posłannictwo i pełnomocnictwo (Mk 3, 13 par.; J 17, 18), stawiając przy tym znak równości pomiędzy własnym i ich autorytetem (Łk 10, 16). Dla wypełnienia zleconych zadań obiecał im nadto osobistą pomoc (Mt 16, 18; 28, 20; Łk 22,

10 Oświadczenie kardynała J. Döpfnera, w: „Życie i Myśl”, 6 (1975) 125-128; Kardinal König: Neuer Stil ist erfreulich, w: „L'Osservatore Romano. Wochenausgabe in Deutscher Sprache", Nr. 9, 28. Februar 1975.

${ }_{11} \mathrm{Z}$ bogatej literatury przedmiotu: L'infaillibilité. Son aspect philosophique et théologique. Actes du Colloque organisé par le Centre international d'études humanistes et par L'institut d'études philosophiques de Rome. Rome, 5-12 Janvier 1970. Aux soins de E. Castelli, Paris 1970 (Aubier); „Concilium. Revue internationale de théologie", No 83 (1973); "Internationale katholische Zeitschrift”, 2/1974; G. Bavaud, Les Eglises face au problème de l'infaillibilité, w: „Revue de Théologie et de Philosophie", 1 (1973) 32-45; S. J. Hernandez Alonso, La infalibilidad eclesial: problemática, síntesis y evaluación, w: „Dialogo Ecunenico”, 8 (1973) 251-286; L. Hödl, Wie fehlbar und unfehlbar ist die kirchliche Lehrverkündigung?, w: ,Theologie und Philosophie", 48 (1973) 173-193; B. Schuler, Mit welcher Lehrautorität wollte Christus seine Kirche ausgeristet haben, w: „Kyrios”, 13 (1973) 171-196; M. Zalba, Magisterium infallibile in Conciliis Vaticanis I et II, w: „Doctor communis”, 26 (1973) 281-316; H. Chadwick, Quelques reflexions sur le magisterium dans l'Eglise, w: Le service théologique dans L'Eglise, Paris 1974, 163-176; L. Hödl, Der unfehlbare Dienst der Kirche am "Wort des Glaubens» w: ,Münchener theologische Zeitschrift", 25 (1974) 95-117; L. Balter, Nieomylność Encyklik papieskich. Studium teologiczno-historyczne, Warszawa 1975, 473-507 (Bibliografia). 
31 n.), a zwłaszcza szczególną opiekę Ducha Swiętego. „Duch Prawdy” (J 14,17; 15, 26; 16, 13) miał apostołów wyposażyć w „moc świadczenia" o Chrystusie (J 15, 26; Dz 1,8), wprowadzić ich we wszelką prawdę i przypomnieć wszystko, co Chrystus im powiedział (J 14, 26; 16, 13 n.). Na skutek tego Duch Święty miał być dla apostołów gwarancją nieutracalnego posiadania prawdy zbawczej i to o eschatologicznej trwałości (J 14, 16). Zstąpienie Ducha Swiętego w dniu Zielonych Swiąt (Dz 2, 1-13) nie było zatem jednorazowym i wyłącznym przywilejem apostołów, lecz trwałym ugruntowaniem Kościoła w prawdzie ( $J$ 17, 17 n.).

Swiadom tego, Kościół pierwotny głosił nieprzerwanie orędzie zbawienia z absolutną pewnością i niekwestionowanym autorytetem. Mimo gróźb i stosowanych represji apostołowie nie godzili się na przerwanie lub ograniczenie przepowiadania ( $\mathrm{Dz} 4,19 ; 29 \mathrm{n}$; $2 \mathrm{Tm} 2$, 9). Ewangelizację uważali za poważny obowiązek przyjęty od Chrystusa (Rz 10, 17; 1 Kor 9, 15 n.) i za pokorną służbę jego Słowu (Dz 6, 2 n.; Ef 4, 14). Byli przekonani, że głoszą nie „siebie samych” lecz „Chrystusa Jezusa” (2 Kor 4, 5), nie „słowo ludzkie” ale „słowo Boga” (1 Tes 2, 13). Wiarygodność i nieskażoność Słowa Bożego była poręczona - w ich przekonaniu specjalną asystencją Ducha Świętego, darem Łaski Bożej (Dz 1, 23-24; 15, 28: „Postanowiliśmy bowiem Duch Święty i my, nie nakładać na was żadnego ciężaru oprócz tego, co konieczne"; por. 1 Kor 7, 25; Tt 1, 9), dlatego domagali się dlań bezwarunkowego posłuszeństwa wiary (Gal 1, 9: „Już to przedtem powiedzieliśmy, a teraz jeszcze mówię: Gdyby wam kto głosił ewangelię różną od tej, którą 'od nas' otrzymaliście - niech będzie wyklęty”). W tym kontekście nazwanie "Kościoła Boga żywego" przez św. Pawła ,filarem i podporą prawdy” (1 Tm 3, 15) jest równocześnie apostolskim wyznaniem wiary w jego nieomylność, która będąc udziałem wszystkich wierzących $\mathrm{w}$ Chrystusa, znajduje w apostołach swych autentycznych heroldów i interpretatorów.

Swiadomość Kościoła odnośnie własnej nieomylności w głoszeniu depozytu wiary, jako rzecz zrozumiała sama przez się, trwała nieprzerwanie przez cały okres patrystyki. Kościół układał formuły chrzcielne, wyznania wiary, teksty liturgiczne do sprawowania służby Bożej uważając je za „regula fidei”, czyli zobowiązującą i pewną normę wiary. Św. Ireneusz († 202) określił Kościół jako „bogaty skarbiec”, w którym przechowuje się wszystko, co należy do prawdy (Adv. haer. III, 4, 1). Na powszechny konsens jako kryterium rozstrzygające w Kościele o prawdzie wiary chrześcijańskiej wskazał św. Wincenty z Lerynu ( $†$ 450) (Comm. 2, 3). Uroczystym poświadczeniem wiary $\mathrm{w}$ nieomylność Kościoła są w owym okresie rozstrzygnięcia doktrynalne wielkich soborów powszechnych. Były one uważane za żywe i wiarygodne przepowiadanie Objawienia stosownie do potrzeb swego czasu i za wierną prawdzie służbę Kościoła. 
Od wieków średnich w Kościele katolickim - ze względu na okoliczności, w jakich się znalazł - obserwuje się ciągle wzrastające zainteresowanie problematyką nieomylności i stopniowe jej zgłębianie. Dla teologów scholastycznych znamienne są następujące sformułowania: „Z wiarą nie może wspólistnieć fałsz” (Fidei non potest subesse falsum); „Kościół powszechny nie może błądzić" (Ecclesia universalis errare non potest) (S. Th., II-II, q. 1, a. 2. 10; Quodl., IX, q. 1, a. 7). W walce z błędnowierczymi ruchami albigensów i waldensów oraz spirytualistycznymi teoriami Wiklefa $(\dagger$ 1384) i Husa ( $\dagger$ 1415), teologia scholastyczna została nadto zmuszona do bliższego określenia roli, jaką w utrzymaniu prawowierności odgrywa Kościół widzialny i jego hierarchia.

Szczególny wpływ na dalszy rozwój kwestii nieomylności kościelnej, i to nie tylko w wiekach średnich lecz i za naszych czasów, miało zamieszanie wywołane schizmą zachodnią i wyrosły z niej koncyliaryzm, który interesował się głównie nieomylnością papieską i jej stosunkiem do nieomylności soborów. Wtedy to bowiem pytania o kompetentne instancje do formułowania doktrynalnych orzeczeń oraz o ich przedmiot, warunki, charakterystyczne cechy czy nawet stopień pewności teologicznej, wysunęły się na pierwszy plan. Natomiast zagadnienie charyzmatycznych podstaw nieomylności - choć nie było całkowicie zapoznane posiadało drugorzędne znaczenie. Dyskusje prowadzone potem na powyższe tematy $\mathrm{w}$ czasie reformacji oraz z jansenizmem, gallikanizmem i febronianizmem nie zmieniły już zasadniczo całokształtu problematyki. Wiele kontrowersyjnych spraw, zwłaszcza odnośnie nieomylności papieskiej, definitywnie rozstrzygnął I Sobór Watykański (1869-1870). Vaticanum II (1962-1965) z kolei decyzje te podjęło i scaliło zarówno z ogólną koncepcją Kościoła jako Ludu Bożego jak i z nauką o nieomylności zjednoczonego z papieżem kolegium biskupów ${ }^{12}$.

\section{b) Nauczanie Vaticanum II}

Wzajemne relacje zachodzące pomiędzy Objawieniem i Kościołem a zwłaszcza jego Magisterium, stanowią istotę problemu nieomylności. Nauczanie II Soboru Watykańskiego pozwala na naszkicowanie następującego ich obrazu.

Objawiony depozyt wiary zawarty w Piśmie św. i Tradycji został powierzony Kościołowi, tzn. całemu Ludowi Bożemu - wiernym świeckim i ich pasterzom. Żyjąc nim, Lud Boży powinien trwać jednomyślnie w wyznawaniu, zachowywaniu i praktykowaniu przekazanej sobie wiary. Co więcej, „ogół wiernych mających namaszczenie od Swiętego (por. $1 \mathrm{~J}$

12 „Rozwój doktryny” został przedstawiony w oparciu o studium: A. Lang, Unfehlbarkeit der Kirche, w: LThK, 10 ('21965) 482-487. 
2, 20 i 27), nie może zbłądzić w wierze i tę szczególną swoją właściwość ujawnia przez nadprzyrodzony zmysł wiary całego ludu, gdy 'poczynając od biskupów aż po ostatniego $z$ wiernych świeckich' ujawnia on swą powszechną zgodność w sprawach wiary i obyczajów. Albowiem dzięki owemu zmysłowi wiary, Lud Boży pod przewodem świętego Urzędu Nauczycielskiego... niezachwianie trwa przy wierze raz podanej świętym (por. Jd 3), wnika w nią głębiej z pomocą słusznego osądu i w sposób pełniejszy stosuje w życiu" (KK 12). Tę nieomylność całego Ludu Bożego, nieomylność, w której przeważają elementy bierne, teologia określa jako „nieomylność wiary” (infallibilitas in credendo). Wypowiedź Vaticanum II pod jej adresem, nie będąc sama w sobie żadną rewelacją doktrynalną, stanowi jednak pewien postęp w stosunku do wcześniejszych enuncjacji na ten temat. Dotychczasowe oświadczenia kościelne w tym względzie dotyczyły bowiem głównie związków istniejących pomiędzy Objawieniem i samym Magisterium, a nie Kościołem jako takim, tzn. całością Ludu Bożego.

Inaczej jednak wygląda problem autentycznej i nieomylnej interpretacji Objawienia, zwanej przez teologów „nieomylnością nauczania” (infallibilitas in docendo). Przysługuje ona wyłącznie ,żywemu Urzędowi Nauczycielskiemu Kościoła - a więc nie wiernym, czy nawet teologom (p. A. K.) - który autorytatywnie działa w imieniu Jezusa Chrystusa" (KO 10). Kolegium biskupie ze swoją głową papieżem, jako następcą dwunastu apostołów z Piotrem na czele, stanowi więc podmiot najwyższej władzy nauczycielskiej w Kościele. Może ją sprawować bądź rozrzucone po świecie (Ecclesia dispersa), bądź też zebrane na soborze powszechnym (Ecclesia coadunata). Ale i sam papież, następca św. Piotra, jest również podmiotem najwyższej władzy nauczycielskiej Kościoła. Dzięki temu stanowi on ,trwałą i widzialną zasadę i fundament jedności wiary i wspólnoty” (KK 18). Owa „personifikacja” Urzędu Nauczycielskiego w biskupie rzymskim - należy to szczególniej podkreślić - nie oznacza jednak ani jego „wyłączności”, ani też „wchłonięcia” kompetencji nauczycielskich episkopatu. Uprawnienia, jakie biskupi posiadają indywidualnie lub kolegialnie w zakresie nauczania pozostają z prawa Bożego nienaruszone. Fakt, że biskup rzymski sam osobiście jest także najwyższym nauczycielem nie ogranicza zatem pełnomocnictw innych biskupów pod tym względem, lecz jedynie przyznaje mu prerogatywy, jakimi obdarza go to samo prawo Boże. Inaczej mówiąc, sam Chrystus zadecydował, że rzeczy tak się mają, aby w swym nauczaniu ,episkopat był jeden i niepodzielony" (KK 18).

Ujmując najogólniej rolę Magisterium względem Objawienia należy stwierdzić, że „nie jest ono ponad Słowem Bożym, lecz jemu służy, nauczając tylko tego, co zostało przekazane" (KO 10). Po prostu, Urząd Nau- 
czycielski Kościoła nie jest „,panem”, lecz „sługą” w odniesieniu do Słowa Bożego. Naucza jedynie rzeczy sobie powierzone. Nie można i nie wolno go zatem uważać za „namiastkę” Chrystusa, zastępującą źródła - Pismo św. i Tradycję. Katolicy tego nie czynią i podobny zarzut ze strony protestanckiej pod ich adresem jest dużym nieporozumieniem.

W szczególności Urząd Nauczycielski ,z rozkazu Bożego i przy pomocy Ducha Świętego słucha pobożnie Słowa Bożego, święcie je strzeże i wiernie wyjaśnia. I wszystko, co podaje do wierzenia jako objawione przez Boga, czerpie z tego jednego depozytu wiary” (KO 10). Wyrażenie „pobożnie słucha” stanowi w przytoczonym tekście pewne ,novum”, wprowadzone przez Konstytucję dogmatyczną Dei verbum. Natomiast dwa następne obowiązki Magisterium, mianowicie konieczność ,świętego strzeżenia” i „wiernego wyjaśniania” Słowa Bożego, występowały już wielokrotnie w różnych dokumentach kościelnych. Zwraca wreszcie uwagę milczenie zacytowanej wypowiedzi, co do piętnowania i zwalczania przez Urząd Nauczycielski błędów zagrażających objawionej wierze.

Rola, jaką spełnia Magisterium w odniesieniu do Objawienia, jest więc silnie zróżnicowana i niezwykle odpowiedzialna. Depozyt wiary, który znajduje się w Piśmie św. i Tradycji, definitywnie zakończony w Chrystusie i ze śmiercią apostołów, nie może ulec istotnej zmianie: pomniejszeniu lub poszerzeniu ( $\mathrm{KK} 25$ ). Ale istnieje rozwój dogmatów, czyli postęp w interpretacji Objawienia, który stanowi lepszą percepcję i głębsze zrozumienie przez Lud Boży objawionych treści. Poszczególne epoki przynoszą bowiem ze sobą nowe odkrycia i naświetlenia, dzięki którym ujawniają się ukryte szczegóły i niejasności stają się zrozumiałe. Wskutek tego Kościół musi ciągle od nowa odczytywać objawioną prawdę uwzględniając postęp ludzkiego poznania. Okazją, czy przyczyną tak pojętego rozwoju doktrynalnego mogą się stać: prześladowania, błędnowierstwo, kontrowersje teologiczne, postęp nauki, prywatne objawienia, itp. Zresztą każdy okres historii Kościoła posiada pod tym względem specyficznie własne doświadczenia. Urząd Nauczycielski ma za zadanie przez autentyczną interpretację depozytu wiary kontrolę tego procesu, czyli ma prawo i obowiązek wydawać sądy o wielu sprawach związanych z Objawieniem. Przede wszystkim rozstrzyga on, co jest objawione, a co nie. Następnie wyciąga wnioski z Objawienia i precyzuje, które twierdzenia są z nim nierozerwalnie związane. Wreszcie może się wypowiadać na temat istniejących relacji pomiędzy Objawieniem i naturalnym poznaniem.

Należy jednak podkreślić, że istnieją różne formy i stopnie zaangażowania się ze strony Urzędu Nauczycielskiego Kościoła w wiarygodny wykład objawionego depozytu. Może być ono uroczyste i bezwzględnie nieomylne, jak to ma miejsce $\mathrm{w}$ definicjach dogmatycznych, które pre- 
cyzują, że dana prawda została przez Boga objawiona i stanowi konieczny przedmiot wiary. Ale częściej bywa zwykłe i względnie omylne, tzn., że nie wyklucza pod każdym względem możliwości pomyłki i dalszych korektur. Przy ustalaniu wartości doktrynalnej jakiegoś twierdzenia teologicznego powinno się więc zbadać, z jakim stopniem zaangażowania Magisterium ma się do czynienia.

W tej pracy - z woli Bożej - Magisterium cieszy się charyzmatem specjalnej opieki Pana i asystencją Ducha Swiętego. Stanowią one istotny element rozwoju dogmatów, ponieważ nie tylko chronią Kościół przed zbłądzeniem, lecz także prowadzą go do poznania pełnej prawdy.

W sumie, Objawienie mieszczące się w Piśmie św. i Tradycji oraz Magisterium stanowią w ekonomii zbawienia jedną zwartą całość i ,tak ściśle ze sobą się łączą, i zespalają, że jedno bez pozostałych nie może istnieć" (KO 10). Wszelkie próby sztucznego separowania tych rzeczywistości, z natury swej komplementarnych, przynoszą ze sobą tylko ich zniekształcenie. Słowo Boże dociera zatem do Ludzi nieskażone przez Pismo św., Tradycję i Magisterium, choć w każdym wypadku na inny sposób. Pismo św. i Tradycja są dalszą normą wiary, Magisterium zaś jej normą bliższą. Posłuszeństwo należne nauce Kościoła nie jest więc w swych ostatecznych konsekwencjach podporządkowaniem się autorytetowi ludzkiemu, lecz powadze objawiającego się Boga Ojca przez Jezusa Chrystusa w Duchu Swiętym ${ }^{13}$.

\section{POGLĄDY H. KÜNGA I STANOWISKO KONGREGACJI NAUKI WIARY}

Katolicką naukę o nieomylności Kościoła Chrystusowego H. Küng poddał radykalnej reinterpretacji, która całkowicie kwestionuje dotychczasowy jej sens. Spotkało się to z nieprzychylną oceną ze strony wielu teologów o wyrobionym nazwisku. Jeżeli idzie o Kongregację Nauki Wiary, to ta odrzuciła zdecydowanie - jak widzieliśmy — skrajne opinie Künga.

\section{a) Negacja}

Podejmując analizę poglądów H. Künga należy w pierwszej kolejnoścı zwrócić uwagę na klimat oraz język książki Unfehlbar?. Książka ta właściwie tchnie nienawiścią do Kościoła katolickiego. Szczególnie sarkastycznych słów używa Autor w stosunku do Stolicy Apostolskiej. Z reguły określa ją jako „rzymski system”, dołączając często do tej nazwy złośliwe epitety ${ }^{14}$. „Rzymski system" - jego zdaniem — praktykuje najgorsze tra-

13 Por. A. Kubiś, Urząd nauczycielski papieża $w$ świetle I i II Soboru Watykańskiego, w: „Analecta Cracoviensia”, 3 (1971) 273-293.

14 Dla przykładu niektóre wyrażenia z Unfehlbar?: „rückwärtsblickende, unökumenische, traditionalistisch, nationalistisch und machtpolitsch denkende Kurie" 
dycje reżimów totalitarnych. Znajduje to wyraz w publikowaniu ,,partyjnych dokumentów" (Parteidokumente) o ciasnej, rzymskiej teologii i ideologii ${ }^{15}$ oraz w stosowaniu „represyjnych sankcji” (repressive Massnahmen) za ich nieprzestrzeganie ${ }^{16}$. Papież Paweł VI - twierdzi Küng jest niewątpliwie uczciwym człowiekiem, ale niewolnicze trzymanie się „systemu rzymskiego" sprawiło, że obdarzono go - z okazji polemiki wokół Humanae vitae - przezwiskiem ,arcyreakcjonisty" (Erzreaktio$n \ddot{a} r)^{17}$. Ó napastliwy i wojujący żargon książki Unfehlbar? na pewno niewiele ma wspólnego z ,umiarkowaniem i rzeczowością" (Bescheidenheit und Sachlichkeit), których Küng domaga się od teologów ${ }^{18}$, przywodzi na pamięć raczej pełną nienawiści walkę klas, niż chrześcijaństwo głoszące miłość Chrystusa.

Główna teza Künga głosi, że tylko Pan Bóg jest nieomylny w pełnym znaczeniu tego słowa. On jeden jedyny ,a priori”, ze swej natury i w każdym przypadku, pozostaje wolny od błędu: nie myli się i nikogo w błąd nie wprowadza. Natomiast składający się z ludzi Kościół, który Bogiem nie jest i nigdy nim nie będzie, może się mylić i innych po ludzku w błąd wprowadzać. Dla uniknięcia wszelkich nieporozumień byłoby lepiej, przy interpretacji obietnic Chrystusa i wiary chrześcijan na ten temat, raczej mówić nie o ,nieomylności” Kościoła (Infallibilität), tylko o jego „nienaruszalności” (Indefektibilität), czy „,trwałości” (Perennität), czyli o tego rodzaju pozostawaniu w prawdzie, które godziłoby się z faktycznym błądzeniem ${ }^{19}$. W tym celu nie wolno utożsamiać nieomylności Kościoła z nieomylnością formułowanych przezeń zdań (Infallible. Sätze). Takich zdań zresztą $\mathrm{w}$ ogóle nie ma $\mathrm{i}$ to zarówno $\mathrm{w}$ dziedzinie dyscyplin świeckich jak i w Piśmie św., nauczaniu Magisterium i teologii. Nie są nimi także dogmaty Kościoła ogłaszane przez sobory powszechne i papieży definicjami ex cathedra. Każde bez wyjątku ludzkie zdanie może być bowiem równocześnie fałszywe i prawdziwe - zależnie od okoliczności, a więc: intencji podmiotu, który je wypowiada; adresata, do którego się zwraca; celów, jakim służy; formy, w jakiej się wyraża. Zdania formułujące wiarę Kościoła są również ludzkimi zdaniami i wskutek tego pozostają omylne ${ }^{20}$. Tym wszystkim jednak nie trzeba się martwić, według Künga, ponieważ „Kościół utrzyma się w prawdzie, pomimo wszystkich zawsze możliwych błędów" 21.

(s. 12); „das alte römische System fürstlicher Dispensen und Privilegien” (s. 16); ,das römische System ist das einzige absolutistische System" (s. 22), itd.

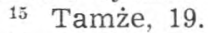

16 Tamże, 62 .

17 Tamże, 32 .

18 Tamże, 196.

19 Tamże, 151.

20 Tamże, 128-141.

21 Tamże, 143: "Die Kirche wird in der Wahrheit erhalten, trotz aller immer möglichen Irrtümer". 
Ten pogląd - zdaniem Künga - nie tylko da się obronić, ale nadto posiada duże zalety. Pismo św. potwierdza jedynie trwanie Kościoła w prawdzie, nigdzie nie mówiąc o jakichś jego nieomylnych sądach. W dotychczasowej swej historii prawdziwy Kościół Chrystusowy istnieje na świecie, mimo że jego Urząd Nauczycielski popełniał liczne błędy. Wprawdzie Vaticanum I i II oraz neoscholastyczna teologia nie biorą pod uwagę tego sensu dogmatu o nieomylności Kościoła, ale nie ulega wątpliwości, że tylko to ujęcie pozwoli katolicyzmowi wycofać się z zaułka wielu anachronistycznych pozycji i przystosować Kościół do współczesnych warunków życia 22.

Teolodzy tej miary co: K. Rahner, L. Sartori, J. Ratzinger, W. Brandmüller, K. Schnackenburg, L. Scheffczyk, Y. Congar, O. Semmelroth, H. Fries, H. Mühlen, J. Alfaro, E. Klinger, K. J. Becker, H. Vorgrimler, K. Lehmann, podjęli na kamach Quaestiones disputate, $54{ }^{23}$ pod redakcją K. Rahnera problematykę nieomylności Kościoła we wszystkich aspektach filozoficzno-teologicznych, a więc językowym, egzegetycznym, historyczno-dogmatycznym. Teolodzy ci przyznając niektórym postulatom Künga ich rzeczywisty walor, np. co do potrzeby zastąpienia bardzo często mylnie rozumianego pojęcia „nieomylność” przez lepsze, reprezentują jednak w tym zbiorowym dziele stanowisko doń przeciwstawne.

Po wszystkim, co napisano na ten temat, wydaje się, że Küng podejmując przy aktualnym stanie wiedzy teologicznej prawie wszystkie problemy postawione w swoim czasie przez modernizm odnośnie natury dogmatów, wzajemnych relacji pomiędzy Magisterium i żywą wiarą wspólnoty Kościoła, znaczenia i roli teologii, bez pogłębionego uwzględnienia niezmiernie dyskusyjnych zagadnień filozoficznych dotyczących poznania analogicznego i filozofii języka - co nawiasem mówiąc przekracza dzisiaj siły jednego, nawet zdolnego teologa - przedstawił opinii publicznej chrześcijan raczej manifest propagandowy, niż dojrzałe rozwiązanie całej skomplikowanej problematyki. W każdym razie dwieście stron jego książki Unfehlbar? nie mogło starczyć na rozwiązanie problematów E. Leroy, G. Tyrella i innych koryfeuszy modernizmu.

\section{b) Interwencja}

Zasadnicze swoje stanowisko w sprawie H. Künga Kongregacja Nauki Wiary sformułowała w Deklaracji Mysterium Ecclesiae. Na baczną uwagę zasługują zarówno forma jak i treść tego dokumentu kościelnego ${ }^{24}$.

22 Tamże, 143-145.

23 Por. przypis 2.

24 Zob. K. Rahner, Mysterium Ecclesiae. Zur Erklärung der Glaubenskongregation über die Lehre von der Kirche, w: ,Stimmen der Zeit”, 191 (1973) 579-594; K. Lehman, Die Debatte um Küngs „Unfehlbar? und der römische Einspruch”, w: 
Deklaracja nikogo nie potępia, nie czyni żadnej wzmianki o sankcjach i unika zniesławiającego języka. Przedstawia jedynie soborową naukę w kwestii nieomylności Kościoła, kładąc przy tym akcent na pozytywny wykład problematyki. Dopiero na dalszym planie są wymienione błędy i podane przestrogi. Deklaracja powołuje się także na stanowisko zajęte przez różne konferencje episkopatu, co niewątpliwie mocno podkreśla rolę Kościołów lokalnych w autentycznym przepowiadaniu wiary. Co więcej, numery drugi i piąty Deklaracji zawierają punkty, które mogłyby stać się podstawą do dialogu i zbliżenia nawet z samym Küngiem.

Jeżeli idzie o treść Deklaracji, uderza w niej równoczesność kilku wątków. Jest ich trzy: nr 1 omawia problem jedności Kościoła, numery 2-5 są poświęcone jego nieomylności, a nr 6 interesuje się urzędowym kapłaństwem.

W numerze 1, opatrzonym tytułem ,,jedyny Kościół Chrystusa” znalazły wyraźne potwierdzenie przede wszystkim ekumeniczne wypowiedzi Vaticanum II o autentycznych wartościach chrześeijańskich u odłączonych braci. Żąda się w nim również od katolików całkiem jednoznacznie pracy nad przywróceniem naruszonej jedności. Z odrzuceniem spotkały się natomiast opinie stwierdzające, że Kościół Chrystusowy jest jakąś bliżej nieokreśloną sumą Kościołów i wspólnot kościelnych oraz że nigdzie już dzisiaj naprawdę on nie istnieje, lecz ma być przez chrześcijan dopiero odszukany. Zarzut, że nr 1 zawiera tendencje antyekumeniczne, całkowicie nie odpowiada prawdzie.

Numery 2-5 formułują centralną problematykę nieomylności Kościoła. Ważnym jest tutaj to, że nieomylność została przypisana w pierwszym rzędzie całemu Kościołowi ( $\mathrm{nr}$ 2), a nieomylność Urzędu Nauczycielskiego znalazła się na dalszym miejscu (nr 3). Szkoda tylko, że Deklaracja nie podjęła się trudu bliższego zbadania i naszkicowania wzajemnych relacji i zrównoważonego przyporządkowania, jakie zachodzą między nimi. Krótki nr 4 (,Nie należy pomniejszać daru nieomylności Kościoła”) zwraca się najmocniej przeciw tezie Künga o zasadniczym trwaniu Kościoła w prawdzie przy równoczesnym błądzeniu poszczególnych orzeczeń podawanych przez Urząd Nauczycielski jako definitywne. Nr 5

\footnotetext{
„Internationale katolische Zeitschrift”, 5 (1973) 466-472; J. A. López Causo, Se compromete toda la Iglesia en las definiciones dogmáticas? La Declaration "Mysterium Ecclesiae», w: „Estudios Trinitarios", 7 (1973) 413-450; A. Plāmādealā, Hans Küng si Declaratia "Mysterium Ecclesiae», w: "Orthodoxia", 25 (1973) 5-67 + Résumé; M. Seckler, "Mysterium Ecclesiae», w: "Theologische Quartalschrift", 153 (1973) 380-382; H. J. Urban, Katholische Ekklesiologie nach "Mysterium Ecclesiae". Ein abgebrochener Lernprozess?, w: Ökumenische Rundschau", 23 (1974) 62-75; J. Ratzinger, Okumenisches Dilemma? Zur Diskussion um die Erklärung «Mysterium E'cclesiae», w: „Internationale kattholische Zeitschrift”, 1 (1974) 56-63; Didymus, Polemiki wokót watykańskiej Deklaracji, w: „Życie i Myśl”, 12 (1973) 146-154; A. Bardecki, Spór o nieomylność Kościoza, w: „Tygodnik Powszechny”, Nr 37, 16 września 1973.
} 
przestrzegający przed fałszowaniem pojęcia nieomylności przynosi bardzo ważne i ze strony Magisterium w wielu wypadkach także nowe wypowiedzi o historycznym uwarunkowaniu i konieczności interpretacji dogmatów.

Poruszający temat kapłaństwa urzędowego nr 6 szczególnie ostro odrzuca jako nadużycie sprawowanie Eucharystii bez obecności i przewodnictwa wyświęconych księży. Takie postępowanie jest nie tylko niedozwolone, lecz także nieważne.

Omawiana Deklaracja pomimo przyjęcia, potwierdzenia i nakazu ogłoszenia przez Pawła.VI pozostaje aktem różnej od papieża instancji, tzn. Kongregacji Nauki Wiary. Jako taki nie zawiera ona żadnej nieomylnej definicji i w rzeczywistości być nią nie pragnie. Katolicy powinni odpowiedzieć na nią nie tylko wstrzymaniem się od krytyki, zewnętrznym podporządkowaniem (silentium obsequiosum), lecz także wewnętrzną aprobatą (obsequium fidei) w tej mierze, jak tego żąda papież. Nie oznacza to oczywiście bynajmniej, że zawarte w Deklaracji dogmaty ze zwyczajnego lub nadzwyczajnego nauczania zrelatywizowały swój dawny stopień pewności teologicznej i utraciły pierwotną obowiązywalność. Fakt umieszczenia ich bowiem $w$ dokumencie o niższej randzc doktrynalnej nic pod tym względem nie zmienił ${ }^{25}$.

Następna Deklaracja Kongregacji Nauki Wiary w sprawie poglądów H. Künga w pełni podtrzymuje naukę Mysterium Ecclesiae ${ }^{26}$. Za aprobatą i z polecenia papieża Pawła VI Kongregacja napomina Prof. Künga, aby porzucił swoje błędne poglądy i zwraca uwagę, że władza kościelna upoważniła Go do nauczania teologii w duchu doktryny Kościoła, a nie według opinii, które ją zniekształcają lub też poddają w wątpliwość. W szczególności Deklaracja odrzuca trzy błędy doktrynalne: $1^{\circ}$ — pogląd który co najmniej poddaje w wątpliwość sam dogmat o nieomylności Kościoła lub redukuje go do zasadniczej nienaruszalności Kościoła w prawdzie; $2^{\circ}$ - opinię fałszującą pojęcie autentycznego Magisterium Kościoła; $3^{\circ}$ - zapatrywanie, iż przynajmniej w koniecznych przypadkach Eucharystia może być ważnie sprawowana przez ludzi tylko ochrzczonych, a więc bez święceń kapłańskich. Potem Deklaracja zwraca się z apelem do biskupów niemieckich i innych krajów, gdzie przytoczone opinie są podtrzymywane na wydziałach teologicznych, w seminariach duchownych i różnego rodzaju zakładach wychowawczo-naukowych, aby roztoczyli opiekę nad właściwą formacją doktrynalną wiernych. Kapłanom, kazno-

25 Rahner, Mysterium Ecclesiae, 580.

26 Pierwsze reakcje: M. Albus, Neuer Stil eröffnet neuce Chanse, w: „KNA. Katolische Nachrichten. Der Kommentar", Nr 5 (Donnerstag, 20. Februar 1975); pl., Am Ende eines Falls, w: "Christ in der Gegenwart”, 10, 9 März 1975; A. Bardecki, Finał sprawy ks. Künga?, w: ,Tygodnik Powszechny”, Nr 11, 16 marca 1975; M. Horoszewicz, Ks. Küng w Rzymie i Krakowie, w: „Argumenty”, Nr 17, 27 kwietnia 1975. 
dziejom, nauczycielom religii i katechetom Deklaracja przypomina, że z racji spełnianej funkcji mają obowiązek wiernego wyznawania kwestionowanej doktryny Kościoła i takiegoż jej wyjaśniania. Teologów wreszcie Deklaracja prosi, żeby zarówno tajemnicę Kościoła jak i inne tajemnice wiary badali i wyjaśniali $\mathrm{w}$ duchu posłuszeństwa samej wierze dla prawdziwego budowania Kościoła.

Każdy, kto uznaje i akceptuje w Kościele funkcję Urzędu Nauczycielskiego doskonale rozumie przed jak niewdzięcznym zadaniem postawiła ją kontrowersja wokół dogmatu nieomylności Kościoła. Decyzja co do pozytywnego rozwinięcia zakwestionowanych prawd i odrzucenia popełnionych błędów postawiła ją w pośrodku zwalczających się wzajemnie opinii teologicznych. Dlatego słusznie zasługuje na wyróżnienie jej nowy sposób postępowania w tym względzie. Dawniej różnice w doktrynie załatwiało się zwięzłymi dekretami, które z reguły ogłaszały także konsekwencje dyscyplinarne. Dzisiaj - co casus Künga naocznie pokazuje zarzucono tę metodę. Ale może właśnie i z tego powodu należy dawać większe dowody życzliwości i solidarności w stosunku do dobrej woli i delikatnej misji Magisterium.

Narzuca się tutaj ważne pytanie, jakie przyczyny spowodowały ową reorientację w postępowaniu Kongregacji Nauki Wiary odnośnie błędów doktrynalnych w Kościele. Takich przyczyn można by wyliczyć zapewne wiele. Racją teologicznie ważną będzie chyba to, że zadanie Urzędu Nauczycielskiego polega nie tyle na polemice z pojedynczymi teologami, co na przypominaniu badaniom teologicznym wiążącej wiary całego Kościoła, zwłaszcza tam, gdzie jest ona szczególniej zagrożona. Stąd pierwszym adresatem ingerencji z natury rzeczy nie powinna być jednostka, lecz publiczna opinia kościelna. Dla katolickiego teologa z kolei wolność poszukiwań teologicznych w Kościele nie może mieć absolutnego charakteru, ponieważ ma on obowiązek liczyć się ze wspólną wiarą Ludu Bożego, będącą dziełem Ducha Swiętego, i tę wiarę w znaczeniu określonym przez Magisterium respektować.

Objawienie potrzebuje nieomylnego Kościoła głównie ze względu na swój historyczny kontekst, który włącza depozyt wiary w proces zmian dokonywujących się w świecie i ludziach. Słowo Boże wcielając się w ciągle ewolującą rzeczywistość ziemską i rozwój człowieka nie może bowiem ulec zniekształceniu, zatraciwszy swój pierwotny sens. Urząd Nauczycielski Kościoła z woli Chrystusa i w oparciu o Jego autorytet zapewnia orędziu zbawienia $\mathrm{w}$ historycznym rozwoju zasadniczą nienaruszalność. Tę rolę względem objawionej prawdy spełnia również uroczyste 
i zwyczajne Magisterium następcy Piotra, biskupa rzymskiego, którego Kongregacja Nauki Wiary stanowi specjalny organ. Czuwając nad akomodacją wiecznych wartości Objawienia do ciągle zmieniających się warunków egzystencji ludzkiej Kościół z pomocą Ducha Swiętego gwarantuje wierze Ludu Bożego tożsamość treściową przy postępie i zmienności form wyrazu. Ta misja Kościoła jest równocześnie służbą prawdzie zbawczej i szukającemu jej człowiekowi.

\section{L'INFAILLIBILITÉ DE L'EGLISE}

R é s u m é

La personne et la production scientifique de $\mathrm{H}$. Küng ont suscité, après le Vatican II, une vive controverse théologique sur l'infaillibilité de l'Eglise. Même la Congrégation pour la doctrine de la foi devait intervenir dans ce débat à cause des opinions de H. Küng débordant, à ce sujet, l'orthodoxie catholique.

L'étude présente, en premier lieu, la doctrine catholique relative à l'infaillibilité de l'Eglise, tant dans son développement historique depuis les origines bibliques que son état actuel proposé par le Vatican II, en particulier dans les Constitutions „Dei Verbum” et „Lumen Gentium”. Ensuite, on y esquisse la pensée de H. Küng concernant l'infaillibilité de l'Eglise et l'attitude prise vis-à-vis d'elle par des théologiens rénommés ainsi que la Congrégation pour la doctrine de la foi dans les Déclarations de 1973 et de 1975. L'analyse approfondie de ces documents fait voir non seulement leur contenu doctrinal mais aussi la nouvelle façon d'agir du Magistère.

L'infaillibilité en question possède une grande importance pour la Révélation divine et la foi du Peuple de Dieu. Or, grâce à elle l'Eglise dans l'évolution historique, garde leur identité foncière. 